Supplement of Ocean Sci., 15, 1745-1759, 2019

https://doi.org/10.5194/os-15-1745-2019-supplement

(C) Author(s) 2019. This work is distributed under

the Creative Commons Attribution 4.0 License.

(c) (i)

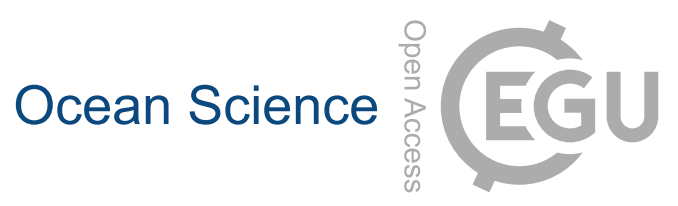

Supplement of

\title{
Influence of the summer deep-sea circulations on passive drifts among the submarine canyons in the northwestern Mediterranean Sea
}

Morane Clavel-Henry et al.

Correspondence to: Morane Clavel-Henry (morane@icm.csic.es)

The copyright of individual parts of the supplement might differ from the CC BY 4.0 License. 


\section{Supporting information}

Table S1. Pelagic Larval Duration (PLD) according to the water temperature by species of the family

Penaeidae

\begin{tabular}{|c|c|c|c|}
\hline Species & PLD (Day) & Water temperature $\left({ }^{\circ} \mathrm{C}\right)$ & Reference \\
\hline \multirow[t]{2}{*}{ Artemesia longinaris } & $\begin{array}{l}24 \\
32\end{array}$ & $\begin{array}{l}24 \\
16\end{array}$ & Boschi and Scelzo, 1974 \\
\hline & $\begin{array}{c}32.5 \\
28\end{array}$ & $\begin{array}{l}17 \\
20\end{array}$ & Boschi and Scelzo, 1977 \\
\hline \multirow[t]{2}{*}{ Litopenaeus stylirostris } & 15 & 30 & Kitani, 1986 \\
\hline & 15 & 28.25 & Prahl and Gardeazábal, 1977 \\
\hline \multirow[t]{2}{*}{ Macropetasma africanus } & $\begin{array}{l}14 \\
25 \\
21 \\
17\end{array}$ & $\begin{array}{l}25 \\
15 \\
18 \\
22\end{array}$ & Cockcroft and Emmerson, 1984 \\
\hline & 19.5 & 22 & Cockcroft, 1985 \\
\hline Metapenaeopsis barbata & 10 & 28.4 & Ronquillo and Saisho, 1997 \\
\hline M. dalei & 15.8 & 25 & Choi and Hong, 2001 \\
\hline M. stridulans & 16.50 & 25.75 & Chong and Sasekumar, 1994 \\
\hline \multirow[t]{4}{*}{ Metapenaeus affinis } & 15.25 & 27.5 & Hassan, 1980 \\
\hline & 15.54 & 26.1 & Muthu et al., 1979a \\
\hline & $\begin{array}{l}13.41 \\
12.56 \\
11.70\end{array}$ & $\begin{array}{l}29.7 \\
28.8 \\
29.7\end{array}$ & Thomas et al., 1974 \\
\hline & 17.25 & 30 & Tirmizi et al., 1981 \\
\hline M. bennettae & 17.07 & 26 & Preston, 1985a \\
\hline M. brevicornis & 23.5 & 27 & Teng, 1971 \\
\hline M. dalli & 12 & 26 & Crisp et al., 2016 \\
\hline M. dobsoni & $\begin{array}{c}15.5 \\
13.33\end{array}$ & $\begin{array}{c}26.15 \\
30\end{array}$ & Chu et al., 1996 \\
\hline \multirow[t]{3}{*}{ M. ensis } & $\begin{array}{l}13 \\
10\end{array}$ & $\begin{array}{l}26 \\
30\end{array}$ & Muthu et al., 1974a \\
\hline & 12.5 & 27 & Leong et al., 1992 \\
\hline & 10.38875 & 29 & Ronquillo and Saisho, 1993 \\
\hline M. joyneri & $\begin{array}{c}22.87 \\
22\end{array}$ & $\begin{array}{c}22.5 \\
24\end{array}$ & Lee and Lee, 1969 \\
\hline M. macleayi & 16.04 & 26 & Preston, $1985 b$ \\
\hline \multirow[t]{2}{*}{ M. monoceros } & 11 & 28 & Kumlu et al., 2001 \\
\hline & 19.16 & 26.1 & Mohamed et al., 1979 \\
\hline \multirow[t]{2}{*}{ M. moyebi } & 14 & 26.5 & Kurata and Vanitchkul, 1974 \\
\hline & $\begin{array}{c}16.39 \\
18.6\end{array}$ & $\begin{array}{l}31 \\
29\end{array}$ & Nandakumar et al., 1989 \\
\hline Parapenaeopsis stylifera & 15.8 & 25 & Hassan, 1984 \\
\hline
\end{tabular}




\begin{tabular}{|c|c|c|c|}
\hline & 20.625 & 26.65 & Muthu et al., 1979b \\
\hline Penaeus aztecus & $\begin{array}{c}17 \\
12.5 \\
11\end{array}$ & $\begin{array}{l}24 \\
28 \\
32\end{array}$ & Cook and Murphy, 1969 \\
\hline P. brevirostris & 9.90 & 27 & Kitani, 1997 \\
\hline \multirow[t]{3}{*}{ P. californiensis } & 11.44 & 29 & Kitani and Alvarado, 1982 \\
\hline & $\begin{array}{l}12 \\
17\end{array}$ & $\begin{array}{c}27 \\
23.5\end{array}$ & Rodriguez de la Cruz, 1975 \\
\hline & $\begin{array}{l}18 \\
14 \\
12 \\
10\end{array}$ & $\begin{array}{l}30 \\
28 \\
25 \\
22\end{array}$ & Villarreal, Hernandez-Llamas, 2005 \\
\hline P. chinensis & 21.29 & 19.5 & Oka, 1967 \\
\hline \multirow[t]{3}{*}{ P. duorarum } & 11 & 28 & Cripe, 1997 \\
\hline & $\begin{array}{c}17.9375 \\
30\end{array}$ & $\begin{array}{l}26 \\
21\end{array}$ & Ewald, 1965 \\
\hline & 10.32 & 30 & Kitani, 1985 \\
\hline P. esculentus & 9.25 & 26.25 & Fielder et al., 1975 \\
\hline P. indicus & 13.565 & 25.6 & Muthu et al, . 1974b \\
\hline \multirow[t]{2}{*}{ P. japonicus } & 12 & 28 & Hudinaga, 1942 \\
\hline & 10 & 28 & Hudinaga and Miyamura, 1965 \\
\hline \multirow[t]{3}{*}{ P. kerathurus } & 12 & 27.5 & Klaoudatos, S., 1978 \\
\hline & 10.375 & 29.5 & Türkmen, 2003 \\
\hline & $\begin{array}{c}16 \\
16.6\end{array}$ & $\begin{array}{l}24 \\
25\end{array}$ & Yufera et al., 1984 \\
\hline \multirow[t]{2}{*}{ P. latisulcatus } & $\begin{array}{c}12.7 \\
31.3 \\
34 \\
21 \\
17 \\
14 \\
\end{array}$ & $\begin{array}{c}24.4 \\
17.1 \\
17 \\
20 \\
22.5 \\
25 \\
\end{array}$ & Roberts et al., 2012 \\
\hline & 8 & 29.2 & Shokita, 1970 \\
\hline P. marginatus & $\begin{array}{l}15 \\
11\end{array}$ & $\begin{array}{l}25 \\
30\end{array}$ & Gopalakrishnan, 1976 \\
\hline \multirow[t]{2}{*}{ P. merguiensis } & $\begin{array}{l}12 \\
11 \\
10 \\
11 \\
11\end{array}$ & $\begin{array}{l}28 \\
28 \\
28 \\
28 \\
28\end{array}$ & Beard, 1977 \\
\hline & 9.25 & 27.5 & Motoh and Buri, 1979 \\
\hline \multirow[t]{2}{*}{ P. monodon } & $\begin{array}{c}10.5 \\
8 \\
14\end{array}$ & $\begin{array}{l}28 \\
33 \\
23\end{array}$ & Reyes, 1985 \\
\hline & 12.41 & 27.5 & Silas et al., 1979 \\
\hline
\end{tabular}




\begin{tabular}{|c|c|c|c|}
\hline & $\begin{array}{c}12 \\
11 \\
8 \\
7 \\
8\end{array}$ & $\begin{array}{l}24 \\
26 \\
28 \\
30 \\
32\end{array}$ & Surech Babu, 2013 \\
\hline & 12.6 & 28.8 & Villalus et al., 1969 \\
\hline P. occidentalis & 10.76 & 27 & Kitani, 1996 \\
\hline \multirow[t]{2}{*}{ P. paulensis } & $\begin{array}{l}25.5 \\
18.5\end{array}$ & $\begin{array}{l}20 \\
25\end{array}$ & Boff and Marchiori, 1984 \\
\hline & 8.5 & 26 & Lemos and Phan, 2001 \\
\hline \multirow[t]{2}{*}{ P. penicillatus } & 8.125 & 31.23 & Heng and Rui-Yu, 1994 \\
\hline & 10 & 25.5 & Pan and Yu, 1989 \\
\hline P. plebejus & 16.48 & 26 & Preston, 1985b \\
\hline P.schmitti & 12.5 & 28.5 & Pinto and Ewald, 1974 \\
\hline \multirow[t]{5}{*}{ P. semisulcatus } & 12.16 & 31 & Devarajan, 1978 \\
\hline & 16.04 & 28 & Hassan, 1982 \\
\hline & $\begin{array}{c}12 \\
26 \\
10 \\
8 \\
8 \\
30 \\
34\end{array}$ & $\begin{array}{c}22 \\
10 \\
26 \\
30 \\
34 \\
8 \\
8\end{array}$ & Kumlu et al., 2000 \\
\hline & 12 & 25.5 & Kungvankij et al., 1972 \\
\hline & 9.30 & 29 & Ronquillo et al., 2006 \\
\hline$P$. setiferus & $\begin{array}{c}11 \\
19.5\end{array}$ & $\begin{array}{l}30 \\
22\end{array}$ & Cook, unpublished \\
\hline P. vannamei & 11 & 33 & Andrade-Vizcaino, 2010 \\
\hline Trachypenaeus curvirostris & 11 & 26 & Ronquillo and Saisho, 1995 \\
\hline
\end{tabular}




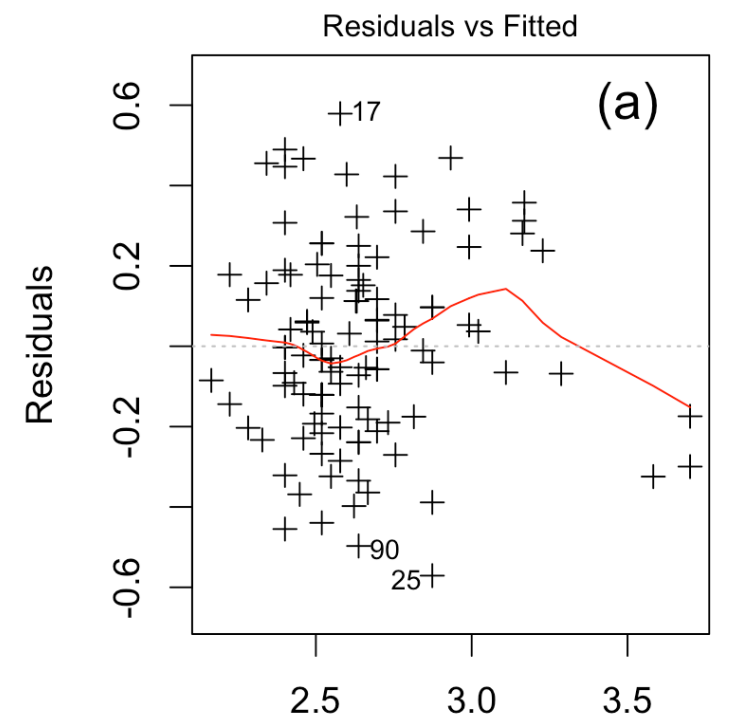

Fitted values

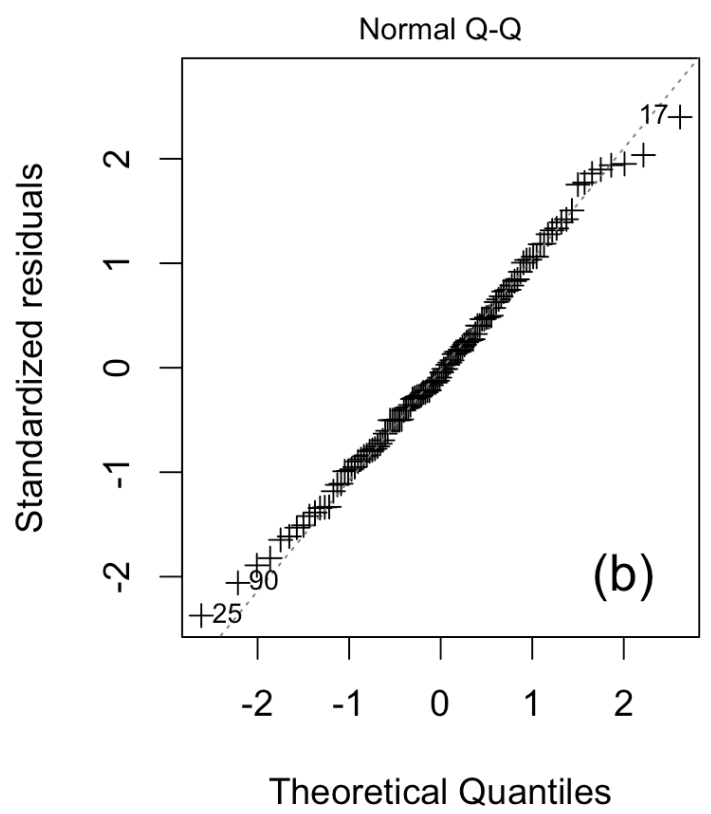

Figure S1. Residuals diagnostics for the linear model of the Pelagic Larval Duration in function of the water temperature. Deviance residuals against linear predictor (a) and QQ-plot of deviance residuals (b). 


\section{References in Table S1}

Andrade-Vizcaino, K., Descripción del desarollo larval del camaron blanco Litopenaeus stylirostris (Boone, 1931), y evaluacion del indice de desarollo en funcion del regimen de alimentacion. (B.S.), Universidad Autonoma de Baja California Sur, La Paz B.C.S, 2010.

Beard, T.W., Wickins, J. F., and Arnstein, D.R., The breeding and growth of Penaeus merguiensis de Man in laboratory recirculation systems, Aquaculture, 10(3), 275-289, doi:10.1016/0044-8486(77)90008-4, 1977

Boff, M.H., and Marchiori, M., The effect of temperature on larval development of the pink shrimp Penaeus paulensis, Atlantica, 7, 7-13, 1984

Boschi, E. E., and Scelzo, M.A., Rearing the Penaeid shrimp Artemesia longinaris from egg to juvenile in the laboratory, Proceedings of the annual meeting - World Mariculture Society, 5(1-4), 443-444, doi: 10.1111/j.1749-7345.1974.tb00211.x, 1974

Boschi, E. E., Scelzo, M. A., Desarrollo larval y cultivo del camaron comercial de Argentina Artemesia longinaris Bate (Crustacea, Decapoda, Penaeidae), FAO- Pesca, 159, 287-327, 1977

Choi, J. H., and Hong, S.H., Larval development of the kishi velvet shrimp, Metapenaeopsis dalei (Rathbun) (Decapoda: Penaeidae), reared in the laboratory, Fishery Bulletin, 99(2), 2001

Chong, V. C., and Sasekumar, A., Larval development of the fiddler shrimp, Metapenaeopsis stridulans (Alcock, 1905) (Decapoda: Penaeidae) reared in the laboratory, Journal of Natural History, 28(6), 12651285, doi: 10.1080/00222939400770641, 1994

Chu, K. H., Sze, C. C., and Wong, C. K., Swimming Behavior during the Larval Development of the Shrimp Metapenaeus ensis (De Haan, 1844) (Decapoda, Penaeidae), Crustaceana, 69(3), 368-378, 1996

Cockcroft, A. C., and Emmerson, W. D., The effect of temperature on the growth, development and survival of Macropetasma africanus (Balss) (Penaeoidea:Penaeidae) larvae reared in the laboratory, Journal of Experimental Marine Biology and Ecology, 84(3), 203-210, doi: 10.1016/0022-0981(84)90180-1, 1994

Cockcroft, A.C., The larval development of Macropetasma africanum (Balss, 1913) (Decapoda, Penaeoidea) reared in the laboratory, Crustaceana, 49(1), 52-74, 1985

Cook, H. L., and Murphy, M. A., The Culture of Larval Penaeid Shrimp, Transactions of the American Fisheries Society, 98(4), 751-754, doi: 10.1577/1548-8659(1969)98[751:TCOLPS]2.0.CO;2, 1969

Cripe, G., Spawning and Larval Survival of the Pink Shrimp, Penaeus duorarum, in a Small Culture Facility, Journal of Applied Aquaculture, 7(1), 29-41, doi: 10.1300/J028v07n01_03, 1997

Crisp, J. A., Tweedley, J. R., D'souza, F. M. L., Partridge, G. J., and Moheimani, N. R., Larval development of the western school prawn Metapenaeus dalli Racek, 1957 (Crustacea: Decapoda: Penaeidae) reared in the laboratory, Journal of Natural History, 1-26, doi: 10.1080/00222933.2016.1155669, 2016

Devarajan, K., Nayagam, J. S., Selvaraj, V., and Pillai, N. N., Larval development-IV . Penaeus semisulcatus de Haan. Larval development of Indian Penaeus prawns, CMFRI Bull., 28(4), 22-30, 1978

Ewald, J. J., The Laboratory Rearing of Pink Shrimp, Penaeus duorarum Burkenroad, Bulletin of Marine Science, 15(2), 436-449, 1965 
Fielder, D., Greenwood, J., and Ryall, J., Larval development of the tiger prawn, Penaeus esculentus Haswell, 1879 (Decapoda, Penaeidae), reared in the laboratory, Marine and Freshwater Research, 26(2), 155-175, doi: 10.1071/MF9750155, 1975

Gopalakrishnan, K. Larval rearing of red shrimp Penaeus marginatus (Crustacea), Aquaculture, 9, 145154, doi: $\underline{10.1016 / 0044-8486(76) 90056-9}, 1976$

Hassan, H., Early developmental stages of Metapenaeus affinis (Decapoda, Penaeidae) reared in a laboratory, ICES Journal of Marine Science, 39(1), 30-43, doi: 10.1093/icesjms/39.1.30, 1980

Hassan, H., The larval development of Penaeus semisulcatus de Haan, 1850 (Decapoda, Penaeidae) reared in the laboratory, Journal of Plankton Research, 4(1), 1-17, 1982

Hassan, H., Larval development of Parapenaeopsis stylifera decapoda penaeidae reared in a laboratory, Journal du Conseil Conseil International pour l'Exploration de la Mer, 41(3), 293-303, 1984

Heng, L., and Rui-yu, L., Comparative studies on the larval development of the penaeid shrimps, Penaeus chinensis, P. merguiensis and P. penicillatus, Chinese Journal of Oceanology and Limnology, 12(4), 295 307, doi: 10.1007/BF02850489, 1994

Hudinaga, M., Reproduction, development and rearing of Penaeus japonicus Bate, Jap. J. Zool., 10, $305-$ 393, 1942

Hudinaga, M., and Miyamura, M., Breeding of the 'Kuruma' prawn (Penaeus japonicus Bate), J. Oceanog. Soc. Japan, 20, 694-706, 1962

Kitani, H., and Alvarado, N., The Larval Devlopment of the Pacific Brown Shrimp Peneaus californiensis HOLMES Reared in the Laboratory, NIPPON SUISAN GAKKAISHI, 48(3), 375-389, doi: 10.2331/suisan.48.375, 1982

Kitani, H., Larval Development of the Pink Shrimp Penaeus duorarum BURKENROAD Reared in the Laboratory and the Comparison with Earlier Descriptions, NIPPON SUISAN GAKKAISHI, 51(8), 12391248, doi: $10.2331 /$ suisan.51.1239, 1985

Kitani, H., Larval Development of the Blue Shrimp Penaeus stylirostris STIMPSON Reared in the Laboratory, NIPPON SUISAN GAKKAISHI, 52(7), 1121-1130, doi: 10.2331/suisan.52.1121, 1986

Kitani, H., Larval Development of the Western White Shrimp Penaeus occidentalis Reared in the Laboratory, Fisheries science, 62(6), 883-891, doi: 10.2331/fishsci.62.883, 1996

Kitani, H., Larval Development of the Crystal Shrimp Penaeus (Farfantepenaeus) brevirostris Under Laboratory Conditions, Fisheries Science, 63(2), 218-227, doi: 10.2331/fishsci.63.218, 1997

Klaoudatos, S., Breeding of Penaeus kerathurus larvae in the laboratory as a proposition to culture them on a commercial scale, Thalassografika, 2(1), 99-113, 1978

Kumlu, M., Eroldogan, O. T., and Aktas, M., Effects of temperature and salinity on larval growth, survival and development of Penaeus semisulcatus, Aquaculture, 188(1-2), 167-173, doi: 10.1016/S00448486(00)00330-6, 2000

Kumlu, M., Eroldogan, O. T., Aktas, M., and Sag`lamtimur, B., Larval growth, survival and development of Metapenaeus monoceros (Fabricius) cultured in different salinities, Aquaculture Research, 32(2), 81-86, doi: 10.1046/j.1365-2109.2001.00532.x, 2001 
Kungvankij, P., Ruangpanit, N., Dangsakul, S., and Chirastit, C., An experiment on artificial propagation of Penaeus semisulcatus de Haan, Contribution No 2, Phuket Marine Fisheries Station, 23, 1972

Kurata, H. and Vanitchkul, P., Larvae and early postlarvae of a shrimp, Metapenaeus burkenroadi, reared in the laboratory, Bulletin of the Nansei Fisheries Research Laboratory, 7, 69-84, 1974

Lee, B. D. and Lee, T. Y., Studies on the larval development of Metapenaeus joyneri (Miers), Publication of the Marine Laboratory of the Pusan Fisheries College, 2, 19-25, 1969

Lemos, D. and Phan, N. V. Ontogenetic variation in metabolism, biochemical composition and energy content during the early life stages of Farfantepenaeus paulensis (Crustacea: Decapoda: Penaeidae), Marine Biology, 38(5), 985-997, doi: 10.1007/s002270000516, 2001

Leong, P. K. K., Chu, K. H., and Wong, C. K., Larval development of Metapenaeus ensis (de Haan) (Crustacea: Decapoda: Penaeidae) reared in the laboratory, Journal of Natural History, 26(6), 1283-1304, doi; $10.1080 / 00222939200770731,1992$

Lindner, M. J. and Cook, H. L., Synopsis of biological data on the white shrimp Penaeus setiferus (Linnaeus) 1767, FAO Fisheries Report., 4(57), 1439-1468, 1970

Mohamed, K. H., Muthu, M. S., Pillai, N. N., and George, K.V. Larval development - Metapenaeus monoceros (Fabricius), CMFRI Bull., 28, 50-59, 1979

Motoh, H, and Buri, P., Larvae of Decapod Crustacea of the Philippines-IV Larval Development of the Banana Prawn, Penaeus merguiensis Reared in the Laboratory, NIPPON SUISAN GAKKAISHI, 45(10), 1217-1235, doi: 10.2331/suisan.45.1217, 1979

Muthu, M. S, Pillai, N. N., and George, K.V., Larval development - Metapenaeus dobsoni (Miers), CMFRI Bull., 28, 30-39, 1974a

Muthu, M. S, Pillai, N. N., and George, K.V., On the spawning and the rearing of Penaeus indicus in the laboratory with a note on the eggs and larvae, Indian Journal of Fisheries, 21(2), 1974b

Muthu, M. S., Pillai, N. N., and George, K. V., Larval development - Parapenaeopsis stylifera (H. Milne Edwards), CMFRI Bull., 28, 65-74, 1979a

Muthu, M. S., Pillai, N. N., and George, K. V., Larval development -Metapenaeus affinis (H. Milne Edwards), CMFRI Bull., 28, 40-49, 1979b

Nandakumar G., Pillai N. N., Telang K. Y., and Balachandran K., Larval development of Metapenaeus moyebi (Kishinouye) reared in the laboratory, J Marine Biol Assoc India. Cochin., 31, 86-102, 1989

Oka, M., Studies on Penaeus orientalis, Kishinouye V. Fertilization and development, Bull. Fac. Fish. Nagasaki Univ., 23, 71-87, 1967

Pan, T. H. and Yu, H. P. Larval Development of the Red Tailed Prawn, Penaeus penicillatus Reared in the Laboratory, J.Taiwan Fish. Soc, 17(4), 247-265, 1990

Pinto, L. G. and Ewald, J. J., Desarrollo larval del camarón blanco Penaeus schmitti. Burkenroad, 1936, Boletín del Centro de Investigaciones Biológicas, 12, 1974

Prahl, H.V. and Gardeazábal, M., Descripción de las larvas del camarón azul Penaeus stylirostris Stimpson, Anales del Instituto de Investigaciones marinas de Punta Betín., 9, 157-172, 1977

Preston, N. P., The combined effects of temperature and salinity on hatching success and the survival, 
growth, and development of the larval stages of Metapenaeus bennettae (Racek and Dall), Journal of Experimental Marine Biology and Ecology, 85(1), 57-74, doi: 10.1016/0022-0981(85)90014-0, 1985a

Preston, N. P., Some Factors Affecting the Survival of the Larvae of the Penaeid Prawns Penaeus Plebejus (Hess), Metapenaeus macleayi (Haswell) and Metapenaeus bennettae (Racek and Dall): University of Sydney. 1985b.

Reyes, E. P., Effect of temperature and salinity on the hatching of eggs and larval development of sugpo, Penaeus monodon, Paper presented at the Proceedings of the first international conference on the culture of penaeid prawns/shrimps, Iloilo City, Philippines. 1985.

Roberts, S. D., Dixon, C. D., and Andreacchio, L., Temperature dependent larval duration and survival of the western king prawn, Penaeus (Melicertus) latisulcatus Kishinouye, from Spencer Gulf, South Australia, Journal of Experimental Marine Biology and Ecology, 411, 14-22, doi: 10.1016/j.jembe.2011.10.022, 2012

Rodriguez de la Cruz, M. C., Descripción de las larvas del camaron café Penaeus californiensis Holmes. Instituto Nacional de Pesca, Serie scentifica, 10, 32pp., 1975

Ronquillo, J. D. and Saisho, T., Early developmental stages of greasyback shrimp, Metapenaeus ensis (de Haan, 1844) (Crustacea, Decapoda, Penaeidae), Journal of Plankton Research, 15(10), 1177-1206, doi: $\underline{10.1093 / p l a n k t / 15.10 .1177,1993}$

Ronquillo, J. D. and Saisho, T., Developmental Stages of Trachypenaeus curvirostris (Stimpson, 1860) (Decapoda, Penaeidae) Reared in the Laboratory, Crustaceana, 68(7):833-863, 1995

Ronquillo, JD, Saisho, T. Larval development of Metapenaeopsis barbata (de Haan, 1844) (Crustacea: Decapoda: Penaeidae), Marine and Freshwater Research., 48(5), 401-414, doi: 10.1071/MF93077, 1997

Ronquillo, J. D., Saisho, T., and McKinley, R. S., Early Developmental Stages of the Green Tiger Prawn, Penaeus semisulcatus de Haan (Crustacea, Decapoda, Penaeidae), Hydrobiologia, 560(1), 175-196, doi: $\underline{10.1007 / \mathrm{s} 10750-005-1448-\mathrm{y}, 2006}$

Shokita, S., A note on the development of eggs and larvae of Penaeus latisulcatus Kishinouye, reared in an aquarium, Biol. Monogr. Okinawa, 6, 34-36, 1970

Silas, E. G., Muthu, M. S., Pillai, N. N., and George, K. V., Larval development - Penaeus monodon Fabricus, CMFRI Bulletin, 28, 2-11, 1979

Suresh Babu, C. and Shailander, M., Effect of Salinity and Temperature on Larval Growth and survival of Black Shrimp Penaeus Monodon (Fabricius) in laboratory conditions, International Journal of Biopharma Research, 2(1), 72-77, 2013

Thomas, M. M., Kathirvel, M., and Pillai, N. N., Spawning and rearing of the penaeid prawn, Metapenaeus affinis (H. Milne Edwards) in the laboratory, Indian Journal of Fisheries, 21(2), 543-556, 1974

Teng, S. K., Observations on certain aspects of the biology of Metapenaeus brevicornis (H. MilneEdwards) and Penaeus merguiensis (de Man) in the Brunei Estuarine system. (MSc Thesis), University of Singapore, Singapore. 1971.

Tirmizi, N., Hasan, . M., and Kazmi, Q. B., The larval development and spawning of Metapenaeus affinis (H. Milne Edwards) under laboratory conditions, Pakistan J. Zool., 13(1 and 2), 141-155, 1981

Türkmen, G., Larval development of the grooved shrimp (Penaeus kerathurus Forskal, 1775) under 
laboratory conditions, Turkish Journal of Fisheries and Aquatic Sciences, 3, 97-103, 2003

Villaluz, D. K., Villaluz, A., Ladrera, B., Sheik, M., and Gonzaga, A., Reproduction, larval development and cultivation of sugpo (Penaeus monodon Fabricius). Philipp, J. Sci., 98, 3-4(205-233), 1969

Villareal, H. and Hernandez-Llamas, A., Influence of temperature on larval development of Pacific brown shrimp Farfantepenaus californiensis, Aquaculture., 249(1-4), 257-263, doi: 10.1016/j.aquaculture.2005.03.039, 2005

Yúfera, M., Rodriguez, A., and Lubián, L. M., Zooplankton ingestion and feeding behavior of Penaeus kerathurus larvae reared in the laboratory, Aquaculture, 42(3), 217-224.doi: 10.1016/0044-8486(84)90102-9, 1984 